\title{
Bioclimatic practices in modern residential building design and construction in South-Eastern Nigeria
}

\author{
Peter Uchenna Okoye *1(iD), Obinna George Ogbuagu ${ }^{2}$ (iD), Christian Ifeanyi Ohaedeghasi ${ }^{1}$ (iD), \\ Chukwuemeka $\mathrm{Ngwu}^{3}$ iD \\ ${ }^{1}$ Nnamdi Azikiwe University, Department of Building, Awka, Nigeria \\ ${ }^{2}$ Federal University of Technology, Department of Building, Owerri, Nigeria \\ ${ }^{3}$ Nnamdi Azikiwe University, Department of Quantity Surveying, Awka, Nigeria
}

\begin{abstract}
The prevalence of modern residential buildings without adequate consideration of changes in user's needs and preferences in urban centres of South-eastern Nigeria is becoming more worrisome. This study therefore, evaluated the level of knowledge and implementation of bioclimatic principles/practices in modern residential buildings by building design and construction professionals. It assessed the adequacy of bioclimatic elements and occupant level of satisfaction based on selected environmental performance criteria. It employed survey approach and analysed the survey data using mean score index, correlation coefficient and t-test statistics. The result showed a low level of implementation of bioclimatic principles/practices in spite of high level of knowledge about bioclimatic principles/practices by the building professionals. It also found that bioclimatic elements/features in modern residential buildings were inadequate and thus, high level of occupants' dissatisfaction with environmental performance of the buildings. The study further found that adequacy of bioclimatic elements was significantly and positively correlated with the level of implementation of bioclimatic principles/practices and occupants' level of satisfaction. However, a moderate and insignificant positive relationship was found between the level of knowledge and implementation of bioclimatic principles/practices. This therefore, suggested a need for building professionals to transform their knowledge of bioclimatic principles into practice for an improved performance. This would create a balance between traditional values and modernisation and a more comfortable home for living. The study then advocated for a revisit to existing building design and construction laws, policies and codes, and/or institutionalising new regulations that would accommodate bioclimatic peculiarities of South-eastern Nigeria.
\end{abstract}

\section{Keywords}

Bioclimatic practices; Construction; Design; Modern; Residential building

Received: 17 August 2020; Accepted: 18 September 2020

ISSN: 2630-5771 (online) C 2020 Golden Light Publishing All rights reserved.

\section{Introduction}

Building especially residential buildings consume significant amount of energy [1]. Likewise, the energy consumption associated with buildings has a significant impact on the environment including climate change [2]. Specifically, around $40 \%$ of energy is consumed in buildings worldwide today with more new buildings being built everyday $[3,4]$.

\footnotetext{
Corresponding author

Email: pu.okoye@unizik.edu.ng
} 
In some countries, buildings significantly contribute and account for up to $45 \%$ of the primary energy consumption [5-7]. Similarly, embodied energy and greenhouse gas (GHG) emissions due to building sector amounts to approximately $20 \%$ of the entire global energy consumption and GHG emissions [8].

Unfortunately, Convertino et al. [9] observed that in the last decades, there has been intense internationalisation in architectural style, indifference toward local climatic conditions and tendency to mechanical control of hygrothermal parameters, thus giving rise to increased environmental consequences. Alcázar and Chávez [10] argued that the modern construction practices usually pay little attention to energy efficiency or environmental impacts they cause despite that Gruber et al. [11] have found that the socioeconomic development of modern societies and technological progress give rise to a continuously increasing energy demand. Worse still, the traditional architecture and vernacular buildings which had some attributes of sustainability have been regarded as outdated and old fashioned. The result of this has been attendant energy crisis, climate change, global warming, rising cases of flooding, heat wave, and other associated environmental, economic and social problems $[12,13]$.

In the South -eastern Nigeria, the situation is not different. Urbanisation, exponential urban population growth, advancement in technology and quest for modern lifestyle have induced rapid increase in the number of residential buildings of different kind and size without regard to the principles of bioclimatic architecture and sustainability. The plethora of many sophisticated but ineffective and dysfunctional building stocks has caused an excessive increase in energy consumption due to daily anthropogenic activities, as well as new infrastructure require increased energy use for function properly [14]. This has negated one of the main concerns in sustainability which is consideration to climatic conditions, and has added to the already existing global environmental problems. Although most of these buildings are modern and sophisticated residential buildings, they do not consider attributes of bioclimatic architecture in their design and construction; and thus making them defective in function.

According to the Building Energy Efficiency Guideline for Nigeria, bioclimatic architecture is the design based on climatic consideration which attempt to achieve physical, mental and emotional comfort for occupants with minimum use of resources while taking in to account behavioural and psychological aspects [15]. "Bioclimatic design means that a building is designed in such a way that, based on local climate data, environmental sources such as sun, wind, air, vegetation, soil and sky are taken into consideration as much as possible for heating, cooling and lighting to reduce the overall energy consumption of the building and to provide comfortable and pleasant living spaces for the inhabitants" [16]. It offers energy efficiency, healthy, environmentally friendly and architecturally valuable solutions, and that its criteria are useful on general planning, analysing life cycle and reducing negative impacts on the air, water and soil, and using energy on the most efficient way [16]. Generally, bioclimatic design and construction strategies are energy efficiency approach towards sustainable building [17-21].

However, sophistication in design and construction of modern residential building as a result of advancement in technology and insatiable demand for comfortable living has become another challenge towards achieving these attributes of sustainability. Matolcsy et al. [16] agreed that this has led to over exploitation of resources and a new challenge to sustainability. These have also resulted to physical, mental and emotional discomfort of the occupants, high energy cost, environmental damage, and poor indoor air quality; which are the attributes of unsustainable construction [10].

Furthermore, Motealleh et al. (2018) [22] argued that compatible design is climatically, the closest way of getting the maximum advantage of renewable sources of energy, while at the same time the design minimises the undesirable effects of construction in the environment and causes 
coordination with sustainability. Achieving environmental sustainability can only be approached from the bioclimatic-sustaining perspective, since most of the people who seek to contribute to protecting the environment think to do it from home is the best option [21,23,24]. In view of this, energy crisis and environmental questions have shown up the need for a renewed approach [9]. This has particularly been advocated for modern buildings [25].

Additionally, residential buildings are places where people find themselves to be for a better part of their day [26-29]. Fundamentally, residential buildings should serve as comfort zones for people and offer protection against unfavourable outdoor climatic conditions [17,30,31]. However, people's environmental comfort in a building depends on adaptation with climatic factors such as wind, and sun [22]. Similarly, Zhang et al. [32] stated that the shape, internal spatial arrangement, size of a building and the azimuth of the sun all affect the energy consumption of a building. Regrettably, application of bioclimatic concept in the design and construction of building has not shown any significant results in building operation [21], due to lack of understanding [33]. The formation of Green Building Council of Nigeria (GBCN), and launching of National Building Energy Efficiency Code (BEEC) which emphasises climate adaptive design and construction in 2017 and National Building Code (NBC) in 2006 have not in any way shown any significant impacts [34]. This implies that the collective aim of these policy documents which is to provide practical guide to professionals in Nigeria on how to design, construct and operate more sustainable and comfortable buildings; educate the general public about sustainable measures; and provide clients with information that would help them choose sustainable and comfortable buildings, while taking into account behavioural and psychological factors has not been met [15]. Therefore, the chances of meeting the targets of energy efficiency in buildings based on the National Energy Efficiency Action Plans (20152030) [35] in Nigeria is threatened.
On this premise, it is imperative to establish a link between sustainability and climate responsive building, in which both of them try to reduce energy consumption and create comfort for building's residents [22]. Hence, this study seeks to evaluate the level of knowledge and application of bioclimatic principles/practices in the design and construction of modern residential buildings in the South-eastern Nigeria. It also assesses the adequacy of and level of satisfaction of occupants of modern residential buildings with respect to environmental performance in the area. According to Mohit and Raja [36] and Waziri et al. [37] indicators of residential building satisfaction are important tools for relevant stakeholders in the building industry in terms of practice and policy making. Furthermore, Jamaludin et al. [38] observed that when bioclimatic design strategies are successfully implemented, it does not only reduce energy use, but significantly increases the resident's satisfaction. Therefore, this study raised the following questions which would guide the study as:

1. Is there any relationship between the level of knowledge and level of implementation of bioclimatic principles/practices by building design and construction professionals?

2. What is the relationship between adequacy of bioclimatic elements and level of implementation of bioclimatic principles/practices by building design and construction professionals?

3. What is the relationship between adequacy of bioclimatic elements and occupants level of satisfaction?

\section{The study area}

The study was carried out in the South-eastern Zone of Nigeria. The Zone is located between latitudes $4^{0} 40^{\prime} \mathrm{N}$ and $7^{0} 20^{\prime} \mathrm{N}$ of the equator and longitudes $6^{0} 00^{\prime} \mathrm{E}$ and $8^{0} 20^{\prime} \mathrm{E}$ of the Greenwich Meridian, and also described as the inland region of Nigeria as shown in Fig. 1. The study area occupies about $50,000 \mathrm{~km}^{2}$ of Nigeria's total area of $923,768 \mathrm{~km}^{2}$ [39]. 


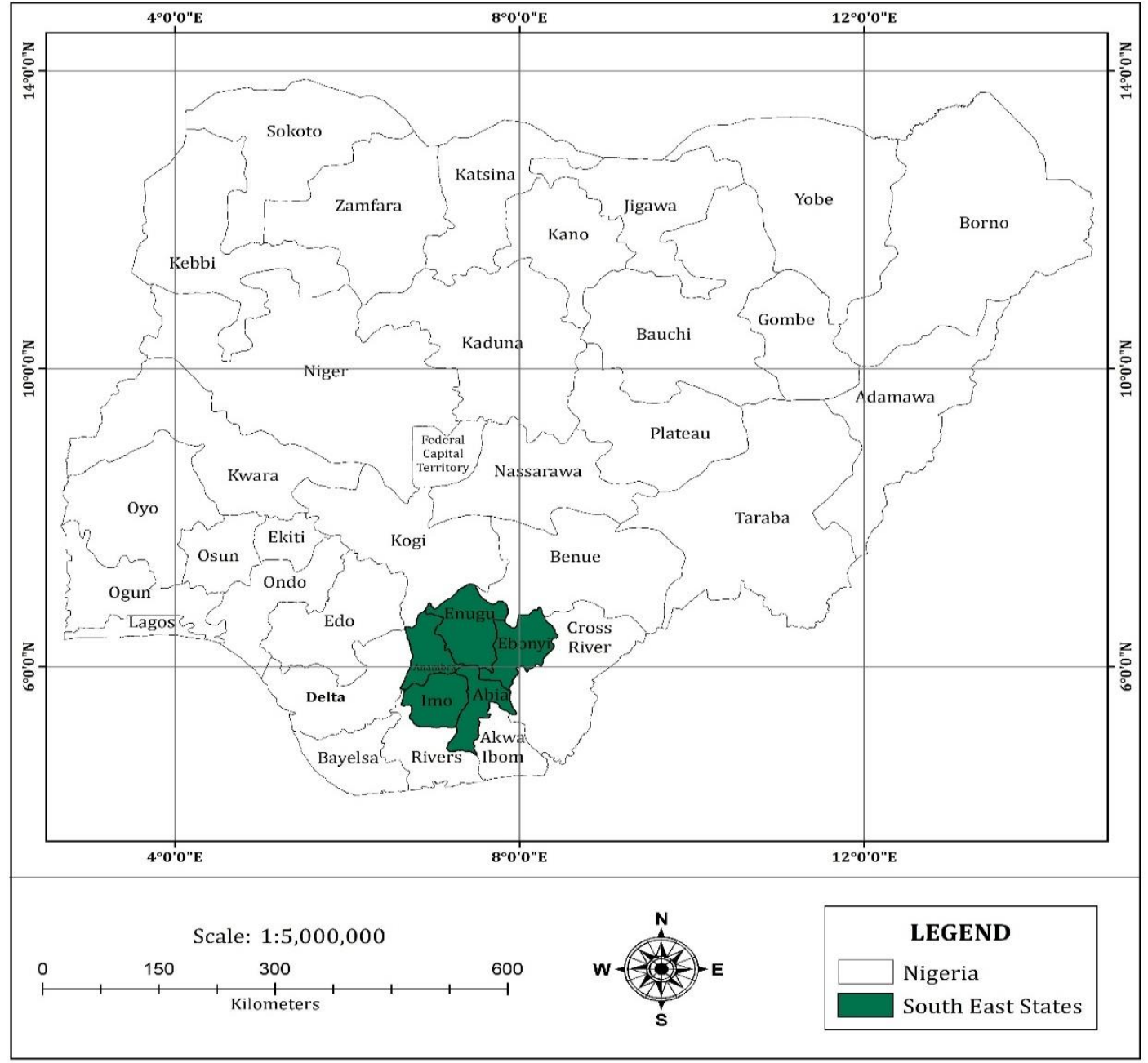

Fig. 1. Map of Nigeria showing the South-eastern region

South-eastern Nigeria is made up of five states comprising Abia, Anambra, Ebonyi, Enugu and Imo. It is bounded to the north by Benue and Kogi states, to the south by Rivers state, to the east by Cross River and Akwa Ibom states and to the west by Delta state. It covers a landmass of 22,525 square kilometres [40], representing about $4 \%$ of the country's land mass [41].

The study area may be classified into two broad relief regions namely lowlands, and cuesta landscapes, divided by Udi escarpment. The lowlands have heights of less than 400 meters and are made up of the Niger-Anambra lowlands in Anambra State and the undulating lowlands and coastal plains located along the Bende-AmekeUmuahia axis of Abia State. The cuesta landscapes of more than 350 meters high comprise the NsukkaOkigwe cuesta and Awka-Orlu uplands [42,43]. The Nsukka-Okigwe cuesta is made up of the Udi escarpments formed by the resistant sandstone in the lower coal measures and in the lower parts of the false bedded sandstone. It has a height of between 370-550 meters and is found in Enugu and Udi areas of Enugu state. The Awka-Orlu uplands are found around the Agulu, Nanka, Oko, Ekwulobia and Onitsha areas of Anambra state and the Bende-Ameke areas of Abia state.

South-eastern Nigeria has a tropical wet and dry climate usually referred to as the tropical rainforest climate. Based on bioclimatic analysis, Nigeria has five climatic regions of which the South-eastern Zone falls within the hot-humid climate except 
Enugu state which falls within the temperate-humid climate [13]. It usually experiences an average of eight months of rainfall between March and October and four months of dry season between November and February. On average, rainfall volumes vary between 1800 meters and 2000 meters [44,45]. It also experiences high temperatures all the year round with an average value of $27^{\circ} \mathrm{C}$, while the average relative humidity ranges between $60-70 \%$ and $80-90 \%$ in January and July respectively [46]. The region is classified under class 2 wind zone (inland cities) with average wind speed of $4.2 \mathrm{~m} / \mathrm{s}$, while the maximum wind power and altitude are $122 \mathrm{w} / \mathrm{s}$ and $167 \mathrm{~m}$ respectively [41].

The area has a lot of vegetation usually mangrove swamp and freshwater swamps. This vegetation zone comprises more than $60 \%$ grass. The soils of the area are composed mainly of iron rich tropical soils, which may be in the forms of loamy, clay, sandstones and sandy clays; and is further classified based on geological formation, landscape features and degree of profile development into lithosols, juvenile soils, ferralitic soils and hydromorphic soils [47-49]. Thus, soil is an invaluable asset within the study area.

The study area has an open and widespread settlement pattern because of the high amount of humidity [50], with population of $16,381,729$ persons according to the 2006 population census [50]. This number was made up of 8,306,306 males and 8,075,423 females [51]. The buildings in this zone seek to integrate spiritual, cultural, and lifestyle values into their design and form [13,52]. The region also has a lot traditional architectural styles with a long narrow building form usually with light and permeable hipped roofs and local building materials such as bamboo, grasses, clay, raffia palms, etc. [13,50,52-55].

Meanwhile the social statistics of the study area revealed that its people are predominantly Christians with high literacy rate. All the states in the region were not classified under educationally less developed states except Ebonyi state. The statistics also showed that there are high volume of modern residential buildings mainly separate houses and flat/apartment houses, scattered both in the urban and rural areas; where most of the buildings are occupied by the renters with average household size of 4.52 persons. Majority (65.81\%) of the working population of the area work in the private sector [56]. The average poverty rate in the area in 2019 was $42.44 \%$ and the average level of inequality was 26.06 [57]. However, in the urban areas of the region especially the state capitals there is almost total absence of users responsive and culturally determined residential buildings due to lack of adequate knowledge of changes in user needs and preferences by the building design and construction professionals and the design of most modern residential buildings based on foreign housing types, culture and lifestyles [57]; and inadequate research on the subject area $[59,60]$. Amidst the foregoing issue, there is phenomenal increase in numbers of residential buildings in the five state capitals of the study area due to high urban population surge [61]. It is against this backdrop that this region was selected for the study, of which the outcome would provide basis upon which building design and construction professionals and government relevant agencies would formulate policies that would incorporate elements of bioclimatic construction in their practice.

\section{Literature review}

Studies on residential building satisfaction have been following four perspectives: sociodemographic characteristics of residents, housing characteristics, neighbourhood characteristics and behavioural characteristics of residents [36,37,62-66]. Although little attention has been given to residential buildings comfort evaluation unlike the commercial and public buildings [67], after the first energy crisis in 1973, bioclimatic design philosophy came to limelight [67]. Since then, there has been a growing interest on reducing dependence on artificial lighting, ventilation and air-conditioning, as well as developing energysmart techniques based on vernacular climatesensitive architecture [68].

Studies have shown that implementation of bioclimatic strategies in design and construction of 
residential buildings is correlated with the resident's satisfaction $[38,67,69]$ as well as minimises energy consumption and improves indoor thermal environment of buildings [19,7074]. Another study [32] has also found that utility, durability and comfort are the three greatest user needs for building. Different bioclimatic practices have been found from the literature as having potentials of improving indoor environmental conditions and minimising energy consumption of residential buildings. These include: Planting trees and vegetation around the building, incorporating artificial water bodies around the building and on the façade, use of glazing wall and fenestration, use of green/living walls, rainwater harvesting, use of large window openings, passive heating and cooling systems, proper insulation of building envelope (opaque structures), right material thickness (thermal mass), proper arrangement of internal room spaces and size, use of shading devices, slanted window/façade, building orientation towards the south, placement of openings, use of solar energy, green roof, adequate air movement using natural ventilation, daylighting, green facades, and acoustic protection [15,16,18-21].

Specifically, Jamaludin [75] found that bioclimatic design strategies including daylighting and natural ventilation at old residential buildings are still appropriate to meet the needs of contemporary life, inasmuch as there is room for improvement especially on the acoustic. Couvelas [76] suggested the use of wind, the use of adaptive building envelopes and shedding systems, surface openings and materials, planting and treating of buildings as living organisms as examples of bioclimatic approaches in building. These views were shared by [25] who suggested the application of public space structure and architectural characteristics such as building form and orientation, openings, central courtyards, wind catchers, roof, wall wings, semi-open spaces and heat capacity of materials in modern buildings. Alabid and Taki [33] presented similar result in a study carried out in Ghadames, Libya. However, in their study, it was revealed that the occupants of the old buildings are more satisfied in terms of indoor environmental conditions, energy consumption, and construction materials, than those occupying the new buildings, and that the locals were not satisfied with the changes in the built environment due to lack of understanding of the sociocultural needs of the local community. Zhang et al. [31] revealed that low energy impact material, orientation, building relationship, and energysaving material are the most important factors to be considered during design and planning of a low environmental impact building. This position was emphasised by $[77,78]$. In carrying out their study, Chávez and Melchor [14] adapted bioclimatic passive techniques such as suitable orientation, appropriate surface colour, solar control, conductive heating and cooling, air movement transfer with a simple wind tower device, thermal mass, thermal insulation, and direct evaporative cooling using a simple geotextile material, among others that are relative and suitable to typical hot dry climate locations in their research work.

Thus, a study carried out by [79] revealed that the users of building lecture hall were dissatisfied with hot and humid indoor environment conditions caused by interactions of local outdoor climatic conditions, the building architecture, and inadequate ventilation within the building. It also revealed that cross-ventilation by the adapted placement of openings, improved external shading devices, and provision of increased vegetation are required in the buildings to achieve a more comfortable indoor environmental quality. Another study conducted by [80] to compare vernacular and new houses in terms of indoor occupant satisfaction and thermal and visual comfort in a cold climate region revealed that the occupant satisfaction in vernacular houses was higher than in new houses. The study suggested that vernacular houses should be an example for the design and construction of new houses in terms of orientation, environment relations, space dimension, and space usage in accordance with the character of the region and material section in order to ensure occupant satisfaction, indoor thermal comfort and healthy environments. 
In Nigeria, some studies have also been conducted. Mohammed and Alibaba [81] revealed that bioclimatic design through the use of local building materials, proper building orientation, incorporating natural landscape, and applying some design elements have potential to limit the effect of heat gain and improve the thermal comfort of indoor environment of residential buildings in Maiduguri, Borno State Nigeria. A similar study conducted by [82] in Minna Niger State also revealed the same result. Yusuf [83] evaluated the application of bioclimatic principles in the design of office buildings in hot-dry climate region of Nigeria. The study found that the design of office buildings in the region has not taken fully cognizance of application of bioclimatic principles. Therefore, building envelope and orientation, renewable energy source, sun shading devices, indoor air and natural cooling elements were recommended in construction office buildings in the area. However, Anumah and Anumah [30] suggested that where north-south orientation of building cannot be achieved in the tropics due to site constraints, vegetation could be provided around the building to improve the microclimate and achieving a comfortable exterior and interior environment. While agreeing with [30], Odunfa et al. [84] stressed that both building material compositions, building orientation and climatic conditions play significant role on energy consumption in a building space.

Another study by [17] evaluated the performance of bioclimatic design building in Nigeria with respect to the architectural elements of thermal comfort, indoor air quality, visual comfort, acoustic comfort and landscape elements. The study revealed that the occupant perceived satisfaction is positively related to the building performance criteria. A related study carried out by [85] on acoustical performance of residential buildings in Awka, Anambra State to determine the level of satisfactions of the occupants also revealed that the overall acoustic performance of the buildings was grossly poor and unsatisfactory, and that the occupant level of satisfaction was positively related to the acoustic performance of the buildings.
Despite the foregoing results, studies dealing with application and occupant satisfaction of bioclimatic design and construction strategies in modern residential buildings in South-eastern Nigeria are grossly inadequate. Interestingly, Daemei et al. [86] and Manzano-Agugliaro et al. [1] suggested that certain bioclimatic design strategies that are adopted in specific cities and countries could be exported to other zones with similar climates due to their proven usefulness as functional architectural design strategies that have resulted to improved human indoor thermal comfort. Therefore, this study vies into exploring and filling this gap in the literature.

\section{Methodology}

This study involved both household and field survey approach in which two sets of questionnaire were administered to the residents and building industry professionals in the South-eastern Nigeria The first questionnaire assessed the availability of bioclimatic elements in the Morden residential buildings and the residents' level of satisfaction with the indoor performance of the buildings in terms of certain environmental performance criteria. The second set measured the professionals' level of knowledge and implementation of bioclimatic strategies in the design and construction modern residential buildings. However, the questionnaires contained 20 bioclimatic elements and 9 performance criteria which formed the basis for assessment. The respondents were then asked to rate their responses on a 5-point Likert scale measurement, where $1=$ very dissatisfied/low, $2=$ dissatisfied/low, $3=$ moderate, $4=$ satisfied/high, $5=$ very satisfied/high. On this basis, there were two sets of respondents for the study. (1) The building professional (specifically, architects, builders and engineers) who are directly involved in the design and construction of building, and (2) the residents (mainly heads of households or representatives).

Since South-eastern Nigeria is currently witnessing undue urbanisation and population surge across the length and breadth of its cities, the capitals of the five states that make of region were selected for this survey. These cities have witnessed 
increased number of residential buildings and population due to their status than any other parts of their respective states. Thus, the population for this study comprises the residents of all the five states capital (Umuahia, Awka, Abakiliki, Enugu and Owerri). According to the National Population Census figure, in 2006, the population of these cities were 362,$192 ; 301,846 ; 149,683 ; 717,291$ and 403,425, for Umuahia, Awka, Abakiliki, Enugu and Owerri respectively [87]. The national average population growth rate in 2006 was $2.83 \%$ [81]. Using national average population growth rate, the population of the study area in 2019 would have been increased exponentially. Therefore, Malthusian growth model represented in Eq. (1) was used to estimate the population of the study area in 2019 based on the national average population growth rate as follows:

$P_{n}=P_{0} e^{r t}$

Where P0 denotes the initial (base year) population $(1,934,437)$; Pn denotes Population in the current year (required population); $\mathrm{r}$ denotes the growth rate $=2.83 \%(0.0283)$ (i.e. national average population growth rate); and $\mathrm{t}$ denotes the time interval (years) $=13$ years.

From Eq. (1), the population of the study is approximately $2,801,952$. To determine the sample size, Israel [88] suggested different ways which include: census for a small population, sample size of a similar study, published table, and the use of formulas. Hence, to determine the appropriate sample size for this study, Cochran's sample size calculation procedure was used which is appropriate when the population of the study is large [89]. Cochran's return sample size formula was first determined using Eq. (2).

$$
n_{0}=\frac{(t)^{2} \times(p)(q)}{(d)^{2}}
$$

Where $\mathrm{n}_{0}$ is the sample size, $\mathrm{t}=$ value for selected alpha level of .025 in each tail $=1.96$ (the alpha level of .05 indicates the level of risk the researcher is willing to take that true margin of error may exceed the acceptable margin of error), $(p)(q)=$ estimate of variance $=0.25$ (maximum possible proportion $(0.5)$ x 1-maximum possible proportion (0.5) produces maximum possible sample size), $d=$ acceptable margin of error for proportion being estimated= 0.05 (error researcher is willing to except).

However, if the computed sample size is greater than $5 \%$ of the population $\left(\mathrm{n}_{0}>5 \%\right.$ population), the final and survey sample size would be calculated using [89]. correction formula in Eq. (3). Otherwise $\mathrm{n}_{0}$ would be adopted as the final and survey sample size for the study.

$n_{1}=\frac{n_{0}}{1+\frac{n_{0}}{\text { population }}}$

From Eq. (2), the sample size:

$n_{0}=\frac{(1.96)^{2} \times(0.5)(0.5)}{(0.05)^{2}} \approx 385$

Since $\mathrm{n}_{0}(385)<5 \%$ of $2,801,952(110,098)$, the survey sample size $\left(\mathrm{n}_{1}\right)=\mathrm{n}_{0}=385$.

Stratified sampling technique was used in selecting the buildings and the respondents based on certain criteria for the first set of the survey. Whereas, a simple random sampling technique was used in choosing the professionals for the second set of the survey. In the first set of survey, only the heads of the household or the representatives were selected for a single family building and for a multifamily building, only one household which was randomly selected was chosen. No two persons were chosen from one building. The selected building must be a modern residential building which has been occupied for up to 1 year but not more than 10 years. For the second set of the survey, only building professionals who were directly involved in the design and construction of buildings were selected. Specifically, the professionals involved were the architects, the builders and engineers.

Since not all respondents were interested in the survey, those who were interested were first identified for familiarisation and consent. The objectives of the study were clearly explained to the participants. This made it easier during the actual survey because the respondents were already aware of what was expected of them, and with the help of an assistant the desired numbers of respondents 
were obtained. In the actual survey, 250 and 135 making a total of 385 copies questionnaire were administered to the two set of the respondents respectively as shown in Table 1 . Likewise, 146 and $91(58.40 \%$ and $67.41 \%)$ copies each making a total of 237 and representing about $61.56 \%$ of the overall were retrieved, and found adequate and suitable to be used for analysis.

The data generated through the questionnaire were descriptively and quantitatively analysed. The adequacy of the bioclimatic elements, occupant level of satisfaction, and the level of knowledge and implementation of bioclimatic strategies by the professional were computed using Mean Score Index (MSI) shown in Eq. (4).

$M S I=\frac{\sum f_{i} x_{i}}{N}$

Where MSI= mean score index; $f=$ frequency of responses to each rating scale (integer value $(i)$ between 1 and 5), $x=$ score or rating given to each variable by the respondents; and $N=$ total number of the respondents selecting a rating equal to $i$. Pearson's Product-Moment Correlation Coefficient(r) was computed to test all the hypotheses. The Pearson's Product-moment Correlation Coefficient ( $r$ ) is calculated using Eq. (5).

$r=\frac{n \sum x y-\sum x \sum y}{\sqrt{\left[n \sum x^{2}-\left(\sum x\right)^{2}\right]\left[n \sum y^{2}-\left(\sum y\right)^{2}\right]}}$

Where, $r=$ correlation coefficient, $n=$ number of pairs of variable being considered, $\mathrm{x}=$ level of satisfaction, and $\mathrm{y}=$ acoustic performance.

However, the value of $r$ ranges from -1 for perfect negative correlation to +1 for perfect positive correlation. Subsequently, in order to infer that the calculated $r$ is applicable to the population from which the sample was drawn, statistical analysis must be performed to determine whether the coefficient is significantly different from zero [90]. This is done by using correlation significant test, with the test statistic ( $\mathrm{t}$ - test) in Eq. (6).

$t=\frac{r \sqrt{n-2}}{\sqrt{1-r^{2}}}$

Where, $\mathrm{r}=$ correlation coefficient, and $\mathrm{n}=$ number of pairs of variables.

The test is a two-tailed, non-directional test. However, in correlation significance test, the sign of the correlation coefficient is always assumed to be positive. The degree of freedom $(\mathrm{df})(\mathrm{n}-2)$ is used at $5 \%$ significant level. The mean values of both variables are used to get their correlation. When Pearson's Product-moment Correlation Coefficients ( $r$ ) between the two variables were computed and their correlation coefficient test obtained at $(n-2)$ degree of freedom and $5 \%(\alpha=$ 0.05 ) significant level, the results obtained are presented in section 4.

Decision: Reject $\mathrm{H}_{0}$ if $\mathrm{t}_{\text {calculated }}>\mathrm{t}$ critical at $\mathrm{df}(\mathrm{n}-2)$ and at 5\% (0.05) significance level otherwise accept $\mathrm{H}_{0}$ and conclude.

To ensure reliability of the result, the margin of error was computed at $95 \%$ confidence interval (C.I) within which the result would be acceptable. Margin of error (ME) is given in Eq. (7) as:

$M E=$ critical value $\mathrm{x}$ standard error

Standard error $=$ standard deviation $/ \sqrt{\mathrm{n}}$

Table 1. Analysis of questionnaire distribution

\begin{tabular}{lllll}
\hline Respondents & $\begin{array}{l}\text { No. of } \\
\text { questionnaire } \\
\text { administered }\end{array}$ & $\begin{array}{l}\text { No. of questionnaire } \\
\text { retrieved }\end{array}$ & $\begin{array}{l}\% \text { of questionnaire } \\
\text { retrieved }\end{array}$ & $\begin{array}{l}\% \text { of questionnaire } \\
\text { retrieved from total }\end{array}$ \\
\hline $\begin{array}{l}\text { Heads of household } \\
\text { (Questionnaire 1) }\end{array}$ & 250 & 146 & 58.40 & 37.92 \\
$\begin{array}{l}\text { Professionals } \\
\text { (Questionnaire 2) }\end{array}$ & 135 & 91 & 67.41 & 23.64 \\
Total & 385 & 237 & & 61.56 \\
\hline
\end{tabular}


Where, $\mathrm{n}=$ the sample;

The Alpha level $(\alpha): \alpha=1-\mathrm{C} . \mathrm{I} / 100=0.05$

The critical probability $\left(\mathrm{p}^{*}\right)$ :

$\mathrm{p}^{*}=1-\alpha / 2=1-0.05 / 2=0.975$

The degrees of freedom (df):

$\mathrm{df}=\mathrm{n}-1=385-1=384$

Usually, the critical value has always been expressed as a t-statistic. Therefore, the t-statistic has 384 degrees of freedom and a cumulative probability of 0.975 . From the t-Distribution, the critical value is found to be 1.96 . The result of this study therefore would be acceptable within error margin of $\pm 4.994 \%$-point, and at $95 \%$ confidence level. This is in line with DataStar [91] which suggested that an acceptable margin of error used by survey researchers falls between $4 \%$ and $8 \%$ at the $95 \%$ confidence level.

\section{Result and discussion}

Table 2 showed the level of knowledge of building professionals on bioclimatic principles/practices.
The result revealed that the professionals were very much knowledgeable about bioclimatic strategies. The overall mean score index (4.36) suggested that the level of knowledge on bioclimatic principles/practices by the building professions was very high. The result also showed that there were very few areas of bioclimatic practices which the professionals still have low knowledge of (use of green roof and use of green facades with mean scores of 2.54 and 2.42 respectively). It further showed that the professional had moderate knowledge on the following principles/practices: Use of slanted window/façade (3.90), right material thickness (thermal mass) (3.75), and incorporation of artificial water bodies around the building and on the façade (3.57). It is not surprising the level of knowledge indicated by this result since, this could be as a result of their training experiences and exposure in the field of practices since all the participants were expects in their various fields of practice.

Table 2. Analysis of level of knowledge of bioclimatic principles/practices

\begin{tabular}{|c|c|c|c|c|c|c|c|}
\hline $\mathrm{S} / \mathrm{n}$ & Bioclimatic principles/practices & 1 & 2 & 3 & 4 & 5 & MSI \\
\hline 1 & Planting of trees and vegetation around the building & & & & 26 & 65 & 4.71 \\
\hline 2 & $\begin{array}{l}\text { Incorporation of artificial water bodies around the } \\
\text { building and on the façade }\end{array}$ & & 12 & 33 & 28 & 18 & 3.57 \\
\hline 3 & Use of glazing wall and fenestration & & & & 14 & 77 & 4.85 \\
\hline 4 & Rainwater harvesting & & & & 11 & 80 & 4.88 \\
\hline 5 & Use of large window openings & & & & 51 & 40 & 4.44 \\
\hline 6 & Passive heating and cooling systems & & & 6 & 32 & 53 & 4.52 \\
\hline 7 & Insulation of building envelope (opaque structures) & & & & 31 & 60 & 4.66 \\
\hline 8 & Right material thickness (thermal mass) & & 9 & 31 & 24 & 27 & 3.76 \\
\hline 9 & Arrangement of internal room spaces and size & & & & 3 & 88 & 4.97 \\
\hline 10 & Use of shading devices & & & & 9 & 82 & 4.90 \\
\hline 11 & Use of slanted window/façade & & & 31 & 38 & 22 & 3.90 \\
\hline 12 & Building orientation towards the south & & & 9 & 49 & 33 & 4.26 \\
\hline 13 & Placement of openings & & & & 20 & 71 & 4.78 \\
\hline 14 & Use of solar energy & & & & 2 & 89 & 4.98 \\
\hline 15 & Use of green roof & 11 & 34 & 32 & 14 & & 2.54 \\
\hline 16 & Air movement using natural ventilation & & & & 10 & 81 & 4.89 \\
\hline 17 & Use of day-lighting & & & & 13 & 78 & 4.86 \\
\hline 18 & Use of green facades & 15 & 40 & 19 & 17 & & 2.42 \\
\hline 19 & Acoustic protection & & & 7 & 48 & 36 & 4.21 \\
\hline \multirow[t]{3}{*}{20} & Appropriate surface colour & & & & 5 & 86 & 4.95 \\
\hline & Total & $\begin{array}{l}26 \\
(1.43 \%)\end{array}$ & $\begin{array}{c}95 \\
(5.22 \%)\end{array}$ & $\begin{array}{c}168 \\
(9.23 \%)\end{array}$ & $\begin{array}{c}445 \\
(24.45 \%)\end{array}$ & $\begin{array}{c}1086 \\
(59.67 \%)\end{array}$ & \\
\hline & Average Mean $=4.36$ & & & & & & \\
\hline
\end{tabular}


Table 2 showed the level of knowledge of building professionals on Bioclimatic principles/practices. The result revealed that the professionals were very much knowledgeable about bioclimatic strategies. The overall mean score index (4.36) suggested that the level of knowledge on bioclimatic principles/practices by the building professions was very high. The result also showed that there were very few areas of bioclimatic practices which the professionals still have low knowledge of (use of green roof and use of green facades with mean scores of 2.54 and 2.42 respectively). It further showed that the professional had moderate knowledge on the following principles/practices: Use of slanted window/façade (3.90), right material thickness (thermal mass) (3.75), and incorporation of artificial water bodies around the building and on the façade (3.57). It is not surprising the level of knowledge indicated by this result since, this could be as a result of their training experiences and exposure in the field of practices since all the participants were expects in their various fields of practice.
Table 3 showed the level of implementation or application of bioclimatic principles/practices in modern residential buildings in South-eastern Nigeria. The average mean score index (2.89) depicted that the overall level of practices and implementation of bioclimatic principles/practices in modern residential buildings in the zone was still low despite that there was very high level of knowledge about the principle by the building design and construction professionals. Nevertheless, there were areas of bioclimatic practices which the respondents indicated through the mean score index that they have shown much interest and have been implementing greatly. These include: Placement of openings (4.65), arrangement of internal room spaces and size (4.59), passive heating and cooling systems (4.35), and appropriate surface colour (4.27). The level of implementation of bioclimatic principles in modern residential buildings in the zone could also be linked to the adequacy of bioclimatic elements/features in the buildings which also could have direct or indirect effect on the occupant satisfactions in terms of environmental performance of the buildings.

Table 3. Analysis of level of implementation of bioclimatic principles/practices

\begin{tabular}{|c|c|c|c|c|c|c|c|}
\hline $\mathrm{S} / \mathrm{n}$ & Bioclimatic principles/practices & 1 & 2 & 3 & 4 & 5 & MSI \\
\hline 1 & Planting of trees and vegetation around the building & 10 & 25 & 56 & & & 2.51 \\
\hline 2 & $\begin{array}{l}\text { Incorporation of artificial water bodies around the building } \\
\text { and on the façade }\end{array}$ & 67 & 24 & & & & 1.26 \\
\hline 3 & Use of glazing wall and fenestration & 8 & 13 & 40 & 30 & & 3.01 \\
\hline 4 & Rainwater harvesting & & & 23 & 53 & 15 & 3.91 \\
\hline 5 & Use of large window openings & & 12 & 52 & 27 & & 3.16 \\
\hline 6 & Passive heating and cooling systems & & & 7 & 45 & 39 & 4.35 \\
\hline 7 & Insulation of building envelope (opaque structures) & & & 41 & 50 & & 3.55 \\
\hline 8 & Right material thickness (thermal mass) & 24 & 62 & 5 & & & 1.79 \\
\hline 9 & Arrangement of internal room spaces and size & & & & 37 & 54 & 4.59 \\
\hline 10 & Use of shading devices & & & 40 & 36 & 15 & 3.73 \\
\hline 11 & Use of slanted window/façade & 58 & 29 & 4 & & & 1.41 \\
\hline 12 & Building orientation towards the south & 30 & 38 & 23 & & & 1.92 \\
\hline 13 & Placement of openings & & & & 32 & 59 & 4.65 \\
\hline 14 & Use of solar energy & 18 & 60 & 13 & & & 1.95 \\
\hline 15 & Use of green roof & 83 & 8 & & & & 1.09 \\
\hline 16 & Air movement using natural ventilation & & & 37 & 44 & 10 & 3.70 \\
\hline 17 & Use of day-lighting & & & 40 & 25 & 26 & 3.85 \\
\hline 18 & Use of green facades & 67 & 24 & & & & 1.26 \\
\hline 19 & Acoustic protection & 30 & 52 & 9 & & & 1.77 \\
\hline \multirow[t]{4}{*}{20} & Appropriate surface colour & & & 20 & 26 & 45 & 4.27 \\
\hline & Total & 395 & 347 & 410 & 405 & 263 & \\
\hline & & $(21.70 \%)$ & $(19.07 \%)$ & $(22.53 \%)$ & $(22.25 \%)$ & $(14.45 \%)$ & \\
\hline & Average Mean $=2.89$ & & & & & & \\
\hline
\end{tabular}


Table 4 showed the adequacy of bioclimatic elements/features in the modern residential buildings in South-eastern Nigeria. It revealed that the overall elements of bioclimatic construction in the buildings were generally low and inadequate with the average mean score of 2.62. However, certain elements such as use of day-lighting (4.51), appropriate surface colour (4.45), arrangement of internal room spaces and size (4.08), and placement of openings (4.04) were found to be adequate. Whereas some other elements such as right material thickness (thermal mass) (3.66), rainwater harvesting (3.38), air movement using natural ventilation (3.34), and use of large window openings (3.21) were moderately adequate. This result suggested that the general inadequacy of bioclimatic elements in modern residential building could be as a result of low/poor implementation.

Table 5 showed the result of the satisfaction level modern residential buildings occupants based on certain environmental performance criteria. The result revealed that the occupants were generally dissatisfied with the environmental performance of the buildings with average mean score index of 2.70. But amidst this result, the occupants were moderately satisfied in some areas such as ventilation (3.90), visual comfort (3.42), and utility (3.31). This implied that the buildings only slightly met the environmental performance criteria of the occupants in these three areas, but were grossly underperformed in other areas. This could also be linked to the inadequacy of bioclimatic elements/features in the buildings.

Table 4. Analysis of adequacy of bioclimatic elements/features

\begin{tabular}{|c|c|c|c|c|c|c|c|}
\hline $\mathrm{S} / \mathrm{n}$ & Bioclimatic elements/features & 1 & 2 & 3 & 4 & 5 & MSI \\
\hline 1 & $\begin{array}{l}\text { Planting of trees and vegetation around } \\
\text { the building }\end{array}$ & 69 & 41 & 24 & 12 & & 2.42 \\
\hline 2 & $\begin{array}{l}\text { Incorporation of artificial water bodies } \\
\text { around the building and on the façade }\end{array}$ & 124 & 22 & & & & 1.15 \\
\hline 3 & Use of glazing wall and fenestration & 21 & 45 & 56 & 24 & & 2.57 \\
\hline 4 & Rainwater harvesting & & 16 & 75 & 38 & 17 & 3.38 \\
\hline 5 & Use of large window openings & 13 & 17 & 63 & 32 & 21 & 3.21 \\
\hline 6 & Passive heating and cooling systems & 44 & 66 & 28 & 8 & & 2.05 \\
\hline 7 & $\begin{array}{l}\text { Insulation of building envelope } \\
\text { (opaque structures) }\end{array}$ & 45 & 70 & 31 & & & 1.90 \\
\hline 8 & $\begin{array}{l}\text { Right material thickness (thermal } \\
\text { mass) }\end{array}$ & & 12 & 36 & 88 & 10 & 3.66 \\
\hline 9 & $\begin{array}{l}\text { Arrangement of internal room spaces } \\
\text { and size }\end{array}$ & & & 34 & 66 & 46 & 4.08 \\
\hline 10 & Use of shading devices & 30 & 46 & 51 & 19 & & 2.40 \\
\hline 11 & Use of slanted window/façade & 86 & 45 & 15 & & & 1.51 \\
\hline 12 & Building orientation towards the south & 79 & 59 & 8 & & & 1.51 \\
\hline 13 & Placement of openings & & & 30 & 80 & 36 & 4.04 \\
\hline 14 & Use of solar energy & 64 & 70 & 12 & & & 1.64 \\
\hline 15 & Use of green roof & 100 & 46 & & & & 1.32 \\
\hline 16 & $\begin{array}{l}\text { Air movement using natural } \\
\text { ventilation }\end{array}$ & & 27 & 61 & 40 & 18 & 3.34 \\
\hline 17 & Use of day-lighting & & & 4 & 64 & 78 & 4.51 \\
\hline 18 & Use of green facades & 43 & 76 & 27 & & & 1.89 \\
\hline 19 & Acoustic protection & 13 & 89 & 44 & & & 2.21 \\
\hline \multirow[t]{3}{*}{20} & Appropriate surface colour & & & 8 & 65 & 73 & 4.45 \\
\hline & Total & $\begin{array}{l}731 \\
(25.03 \%)\end{array}$ & $\begin{array}{l}747 \\
(25.58 \%)\end{array}$ & $\begin{array}{l}607 \\
(20.79 \%)\end{array}$ & $\begin{array}{l}536 \\
(18.36 \%)\end{array}$ & $\begin{array}{l}299 \\
(10.24 \%)\end{array}$ & 2.62 \\
\hline & Average Mean $=2.62$ & & & & & & \\
\hline
\end{tabular}


Table 5. Analysis of occupant level of satisfaction

\begin{tabular}{|c|c|c|c|c|c|c|c|}
\hline $\mathrm{S} / \mathrm{n}$ & Environmental performance criteria & 1 & 2 & 3 & 4 & 5 & MSI \\
\hline 1 & Energy consumption & 23 & 55 & 29 & 39 & & 2.58 \\
\hline 2 & Indoor thermal comfort & 48 & 72 & 26 & & & 1.85 \\
\hline 3 & Utility & & & 25 & 76 & 45 & 3.31 \\
\hline 4 & Visual comfort & & 23 & 40 & 61 & 22 & 3.42 \\
\hline 5 & Acoustic comfort & 46 & 84 & 16 & & & 1.79 \\
\hline 6 & Healthy environment & 32 & 75 & 39 & & & 2.05 \\
\hline 7 & Indoor air quality & 18 & 67 & 52 & 9 & & 2.36 \\
\hline 8 & Ventilation & & 11 & 25 & 77 & 33 & 3.90 \\
\hline \multirow[t]{3}{*}{9} & Outdoor environmental comfort & 44 & 57 & 45 & & & 2.01 \\
\hline & Total & $\begin{array}{l}211 \\
(16.06 \%)\end{array}$ & $\begin{array}{l}444 \\
(33.79 \%)\end{array}$ & $\begin{array}{l}297 \\
(22.60 \%)\end{array}$ & $\begin{array}{l}262 \\
(19.94 \%)\end{array}$ & $\begin{array}{l}100 \\
(7.61 \%)\end{array}$ & \\
\hline & Average Mean $=2.70$ & & & & & & \\
\hline
\end{tabular}

But the fact that the building occupants surveyed were not building industry professionals and might not have the full knowledge of building design and construction vis-à-vis bioclimatic concept could be a reason they might not have substantial input in the design and construction of the buildings [58]. This could be attested from the result, as their level of knowledge was limited to basic environmental performance criteria such as ventilation, visual comfort and utility. Secondly, most of the occupants were renters and do not have any input in the design and construction of the building they live in [85]. Besides, home owners are more likely to express satisfaction with their houses than tenants [59]. In addition, the respondents were residents of the capital cities of the respective states in the study area, therefore were more enlightened in what was expected of a modern residential building for optimal satisfaction.

To further substantiate these results, three null $\left(\mathrm{H}_{0}\right)$ hypotheses which were formulated were tested. The hypotheses are as follows:

1. There is no significant relationship between the level of knowledge and level of implementation of bioclimatic principles/practice by building design and construction professionals.

2. There is no significant relationship between adequacy of bioclimatic elements and level of implementation of bioclimatic principles/practice by building design and construction professionals.
3. There is no significant relationship between adequacy of bioclimatic elements and level of satisfaction occupants of modern residential buildings.

Table 6 showed the result of correlation analysis between the level of knowledge and level of implementation of bioclimatic principles/practices by the building design and construction professionals. The correlation coefficient $(\mathrm{r}=$ 0.547) indicated that there was moderate positive correlation between the level of knowledge and level of implementation of bioclimatic principles/practices by the building design and construction professionals in the zone. The coefficient of determination result $\left(R^{2}=0.2992\right)$ revealed that the level of implementation of bioclimatic principles/practices by the building design and construction professionals was only minimally influenced by the professionals' level of knowledge on bioclimatic principles/practices. It specifically showed that about $29.92 \%$ of the level of implementation of bioclimatic principles/practices was being caused by the professionals' level of knowledge. This suggested that besides, the basic and acquired knowledge gained by the professionals in the course of their training and practice, there are other factors which could contribute substantially to the implementation of bioclimatic principles/practices in building practices in the study area. 
Table 6. Correlation between the level of knowledge and level of implementation of bioclimatic principles/practices

\begin{tabular}{|c|c|c|c|c|c|c|}
\hline $\begin{array}{l}\text { Correlation } \\
\text { Coefficient (r) }\end{array}$ & Nature of Association & $\mathrm{t}$ - test value & $\mathrm{T}_{\text {critical }}$ & $\mathrm{R}^{2}$ & $p$-value & Decision \\
\hline 0.547 & $\begin{array}{l}\text { Moderate positive } \\
\text { correlation }\end{array}$ & 1.312 & 3.182 & $\begin{array}{l}0.2992 \\
(29.92 \%)\end{array}$ & .340 & Accept $\mathrm{H}_{0}$ \\
\hline
\end{tabular}

When the correlation was further tested for significance at $5 \%$ significance level $(\alpha=0.05)$, the result revealed that $t_{\text {calculated }}(1.312)$ was less than $\mathrm{t}_{\text {critical }}$ (3.182). Conversely, the computed p-value (.340) was greater than $\alpha=.05$. Hence, since the $t_{\text {calculated }}(1.312)<t_{\text {critical }}(3.182)$ and the $p$-value (.340) $>\alpha(.05)$, the $\mathrm{H}_{0}$ was accepted and the study concluded that there is no significant relationship between the level of knowledge and level of implementation of bioclimatic principles/practices by the building design and construction professionals. This result implied that the level of implementation of bioclimatic principles/practices by the building professionals in the South-eastern Nigeria is not commensurate with the level of knowledge of bioclimatic principles/practices by the professionals. This could be as a result of other exigencies which still need to be verified. This has therefore substantiated by the results of Tables 2 and 3 .

Table 7 showed the result of correlation analysis between adequacy of bioclimatic elements and level of implementation of bioclimatic principles/practices by the building design and construction professionals. The correlation coefficient $(r=\mathbf{0 . 8 9 3})$ revealed that there was high positive correlation between adequacy of bioclimatic elements and level of implementation of bioclimatic principles/practices in the zone. The coefficient of determination result $\left(\mathrm{R}^{2}=0.7974\right)$ implied that the inadequacy of bioclimatic elements in the modern residential buildings was as a result of low implementation of bioclimatic principles/practices by the building design and construction professionals. Specifically, the result revealed that about $79.74 \%$ of the cause of inadequacies of bioclimatic elements in the buildings could be attributed to the low implementation of bioclimatic principles/practices by the building design and construction professionals.

When the correlation was tested for significance at $5 \%$ significance level $(\alpha=0.05)$, the result revealed that $\mathrm{t}_{\text {calculated }}(3.437)$ was greater than $t_{\text {critical }}$ (3.182). Likewise, the $p$-value (.042) was less than $\alpha=.05$. Since the $t_{\text {calculated }}(3.437)>t_{\text {critical }}$ (3.182) and the $p$-value $(.042)<\alpha(.05), \mathrm{H}_{0}$ was rejected and the study concluded that there was significant relationship between adequacy of bioclimatic elements and level of implementation of bioclimatic principles/practice by the building design and construction professionals. It then suggested that the low implementation of bioclimatic principles/practices by the building professionals contributed substantially to the inadequacies of bioclimatic elements in modern residential buildings in the South-eastern Nigeria which in turn led to dissatisfaction in terms of environmental performance.

Table 8 presented the result of correlation analysis between adequacy of bioclimatic elements and level of satisfaction of occupants of modern residential buildings. The correlation coefficient result $(r=\mathbf{0 . 9 1 4})$ indicated that that there was high positive correlation between adequacy of bioclimatic elements and occupants' level of satisfaction in the zone. The coefficient of determination result $\left(\mathrm{R}^{2}=0.8354\right)$ implied that the inadequacy of bioclimatic elements has resulted to occupants being dissatisfied with the environmental performance of the buildings. This further showed that about $83.54 \%$ of the level of dissatisfaction of occupants were caused by the inadequacies of bioclimatic elements in the modern residential buildings and vice versa, in South-eastern Nigeria. 
Table 7. Correlation between adequacy of bioclimatic elements and level of implementation of bioclimatic principles/practices

\begin{tabular}{lllllll}
\hline $\begin{array}{l}\text { Correlation } \\
\text { Coefficient }(\mathrm{r})\end{array}$ & Nature of Association & $\mathrm{t}-$ test value & $\mathrm{T}_{\text {critical }}$ & $\mathrm{R}^{2}$ & $p$-value & Decision \\
\hline 0.893 & $\begin{array}{l}\text { High positive } \\
\text { correlation }\end{array}$ & 3.437 & 3.182 & $\begin{array}{l}0.7974 \\
(79.74 \%)\end{array}$ & .042 & Reject Ho \\
\hline
\end{tabular}

Table 8. Correlation between adequacy of bioclimatic elements and level of satisfaction occupants of modern residential buildings

\begin{tabular}{lllllll}
\hline $\begin{array}{l}\text { Correlation } \\
\text { Coefficient }(\mathrm{r})\end{array}$ & $\begin{array}{l}\text { Nature of } \\
\text { Association }\end{array}$ & $\mathrm{t}$ - test value & $\mathrm{T}_{\text {critical }}$ & $\mathrm{R}^{2}$ & p - value & Decision \\
\hline 0.914 & $\begin{array}{l}\text { Very high positive } \\
\text { correlation }\end{array}$ & 3.902 & 3.182 & $\begin{array}{l}0.8354 \\
(83.54 \%)\end{array}$ & .030 & $\mathrm{Reject} \mathrm{H}_{0}$ \\
& & & & \\
\hline
\end{tabular}

However, when the significance of the correlation coefficient was tested at 5\% significance level $(\alpha=0.05)$, the result revealed that $t_{\text {calculated }}$ (3.902) was greater than $t_{\text {critical }}$ (3.182). At the same time, the $p$-value (.0430) was less than $\alpha$ $=.05$. Therefore, since the $t_{\text {calculated }}(3.902)>t_{\text {critical }}$ (3.182) and the $p$-value $(.030)<\alpha(.05)$, this study submitted that $\mathrm{H}_{0}$ should be rejected and thus concluded that there was significant relationship between the adequacy of bioclimatic elements and level of satisfaction of occupants of modern residential buildings. This result therefore, affirmed that there is link between the level of implementation of bioclimatic principles/practices, adequacy of bioclimatic elements and level of occupants' satisfaction. It then suggested that the low implementation of bioclimatic principles/practices by the building professionals contributed substantially to the inadequacies of bioclimatic elements which in turn contributed to occupants' dissatisfaction in the environmental performance of modern residential buildings in the South-eastern Nigeria.

In the first instance, this result has shown that the sampled building professionals were experts in their fields of practice when considered the high level of knowledge of bioclimatic principles/practices indicated by the respondents. Surprisingly, the high level of knowledge has not been transmuted into high level of implementation. As a result, a record of low level of implementation of bioclimatic principles/practices by the professionals in the design and construction of residential buildings was found by this study. This suggested that there are other factors other than the knowledge of building design and construction experts alone that greatly influence the implementation of bioclimatic principles/practices in the study area. Part of this could be the sociocultural factors and user's needs and preferences $[58,59]$. This is also in line with the result of [22] which suggested that people's environmental comfort in a building depends on adaptation with climatic factors such as wind, and sun. This result equally aligned with that of [31] and supported by [76,77].

Unfortunately, the low level of implementation of bioclimatic principles/practices has also led to inadequacies of bioclimatic elements in the modern residential buildings in South-eastern Nigeria. As expected, this has caused dissatisfaction among the occupants of the buildings in terms of environmental performance. This equally supports the results of $[37,60,66,68]$ which averred that implementation of bioclimatic strategies in design and construction of residential buildings is correlated with the resident's satisfaction. By implication, this result suggested that ultimate value of most modern residential buildings in the South-eastern Nigeria has not been fully derived despite huge resource commitments. This has seriously negated the cardinal objectives of sustainability, of which one is environmental performance. It also went contrary to the tenets of combined bioclimatic/ecology and regionalist theories which promote the environmental agenda 
in a distinctive regionalism. Therefore, this study infers that the high level of knowledge of bioclimatic principles/practices should have a chain reaction which include implementation vis-à-vis other factors.

\section{Conclusion and recommendations}

In contemporary buildings, the need to optimise the use of bioclimatic strategies in order to minimise the consumption of non-renewable energy and improve the indoor and environmental quality has been advanced. This is because the provision of conducive, safe, comfortable, healthy and secured indoor environment for its occupants as well as social interactions, and improvement of quality of life are the principle objects of a residential building. When these are found wanting, the expectation is usually in the form of occupants' expressed dis/satisfaction. Thus this study has evaluated the level of knowledge and implementation of bioclimatic principles/practices in the design and construction of modern residential buildings. It has also assessed the adequacy of bioclimatic elements and occupant level of satisfaction based on certain environmental performance criteria in South-eastern Nigeria. The study has found that there was low level of implementation of bioclimatic principles/practices in spite of high level of knowledge about bioclimatic principles/practices by the building professionals. The study further found that the resultant effect of low implementation has led to inadequacies in the provision of bioclimatic elements/features in the buildings which further led to the occupants' dissatisfaction of environmental performance of the buildings.

Furthermore, the study found that the level of occupants' satisfaction was significantly and positively correlated with the adequacy of bioclimatic elements. In the same vein, the adequacy of bioclimatic elements was equally significantly and positively correlated with the level of implementation of bioclimatic principles/practices. This suggested that high level of dissatisfaction expressed by the occupants was as a result of inadequacy of bioclimatic elements which was a sprout of low level of implementation of bioclimatic principles/practices by the building professionals.

Implicitly, this study has both practical and policy implications. The study has revealed the need for building design and construction professionals to transform their knowledge of bioclimatic principles into practice for an improved performance. Specifically, designers and builders should optimise such practices as planting of trees and vegetation around the building, incorporation of artificial water bodies around the building and on the façade, use of green facades, use of green roof, use of solar energy, acoustic protection, building orientation towards the south so as to create a balance between traditional values and modernisation and create a more comfortable home for people to live. Secondly, the fact that bioclimatic design and construction has not been infused into the mainstream building practice in our contemporary society is an act of policy and other factors. Thus, this study has called for a revisit to existing building design and construction laws, policies and codes, or institutionalising new regulations that would accommodate the peculiarities of bioclimatic principle. On this premise, this study has provided a basis for formulating policies upon which building design and construction professionals and relevant agencies would incorporate elements of bioclimatic construction in their practice. However, for an effective and workable policy framework, government and construction stakeholders should be involved in the formulation bioclimatic policy for buildings. Specifically, the enforcement within the construction industry should be championed and propelled by the organs of the government and relevant professional groups for a sustainable building. Nevertheless, one major limitation of this study is the sample size which is less than $5 \%$ of the population and might affect the generalisation of the result of this study. 


\section{Ethics committee permit and/or legal/special permission}

The authors confirm that no ethics committee permit was required for data collection through questionnaire, but special permission and consent was sought and obtained from the respondents before they were given the questionnaire to fill.

\section{Declaration of conflicting interests}

The author(s) declared no potential conflicts of interest with respect to the research, authorship, and/or publication of this article.

\section{References}

[1] Manzano-Agugliaro F, Montoya FG, Sabio-Ortega, A, Gracía-Cruz A (2015) Review of bioclimatic architecture strategies for achieving thermal comfort. Renewable Energy and Sustainable Energy Review, 49: 736-755. https://doi.org/10.1016/j.rser.2015.04.095.

[2] Naïma F, Mébirika B, Belkacem D, Claude-Alain $\mathrm{R}$ (2016) The traditional house with horizontal opening: a trend towards zero-energy house in the hot, dry climates. Energy Procedia, 96: 934-944. https://doi.org/10.1016/j.egypro.2016.09.169.

[3] Mirabella N, Röck M, Saade MRM, Spirinckx C, Bosmans M, Allacker K, Psser A (2018) Strategies to improve the energy performance of buildings: A review of their life cycle impact. Buildings, 8: 105. https://doi.org/10.3390/buildings8080105.

[4] World Business Council for Sustainable Development (WBCSD). Transforming the market: Energy efficiency in buildings. Atar Roto Pesse SA, Switzerland, 2009. Retrieved from: www.wbcsd.org/web/eeb.htm. [Accessed 5 June 2020].

[5] P'erez-Lombard L, Ortiz J, Pout C (2008) A review on buildings energy consumption information. Energy and Buildings, 40(3): 394-398. https://doi.org/10.1016/j.enbuild.2007.03.007.

[6] Iwaro J, Mwasha A (2010). A review of building energy regulation and policy for energy conservation in developing countries. Energy Policy, $38(12)$ : 7744-7755. https://doi.org/10.1016/j.enpol.2010.08.027.

[7] dos Santos AHC, Fag'a MTW, dos Santos EM (2013) The risks of an energy efficiency policy for buildings based solely on the consumption evaluation of final energy. International Journal of Electrical Power \& Energy Systems, 44(1): 70-77. https://doi.org/10.1016/j.ijepes.2012.07.017.

[8] Seo S, Passer A, Hajek P, Lützendorf T, Mistretta M, Houlihan Wiberg A. Evaluation of embodied energy and $\mathrm{CO} 2 \mathrm{eq}$ for building construction (Annex 57). Institute for Building Environment and Energy Conservation, Tokyo, Japan, 2016. Retrieved from: www.annex57.org/wp/wpcontent/uploads/2017/05/summary-report.pdf.

[Accessed 5 June 2020].

[9] Convertino F, Di Turi S, Stefanizzi P (2017) The colour in the vernacular bioclimatic architecture in Mediterranean region. Energy Procedia, 126: 211218. https://doi.org/10.1016/j.egypro.2017.08.142.

[10] Alcázar MRT, Chávez JRG (2014). Educational program for promoting the application of bioclimatic and sustainable architecture in elementary schools. Energy Procedia, 57: 9991004.

https://doi.org/10.1016/j.egypro.2014.10.083.

[11] Gruber JK, Prodanovic M, Alonso R (2015). Estimation and analysis of building energy demand and supply costs. Energy Procedia, 83: 216-225. https://doi.org/10.1016/j.egypro.2015.12.176.

[12] Kirubakaran K, Murali K (2016) A critical review on planning and design aspects of sustainable building in different climatic zones. International Journal of Science, Engineering and Technology Research, 5(11): 3198-3202.

[13] Mobolade TD, Pourvahidi P (2020) Bioclimatic approach for climatic classification of Nigeria. Sustainability, $\quad 12$ : 4192. https://doi.org/10.3390/su12104192.

[14] Chávez JRG, Melchor FF (2014) Application of combined passive cooling and passive heating techniques to achieve thermal comfort in a hot dry climate. Energy Procedia, 57: 1669-1676. https://doi.org/10.1016/j.egypro.2014.10.157.

[15] Federal Ministry of Power, Works and Housing (Housing). Building Energy Efficiency Guideline for Nigeria. Federal Ministry of Power, Works and Housing (Housing), Abuja, Nigeria, 2016. Retrieved from: https://energyedia.info/images/c/c7/Building_Ener gy_Efficiency_Guideline_for_Nigeria_2016.pdf. [Accessed 2 February 2020].

[16] Matolcsy K, Budavári Z, Kuthi EB, Frey L, Pando AR, Bartolo EM. Del.2.4.4: Guide for bioclimatic design (Revised Version). EMI and ACCIONA, Budapest and Madrid, 2015. Retrieved from: 
https://smartcities-infosystem.eu/content/pimesguide-bioclimatic-design. [Accessed 22 January 2020].

[17] Akadiri PO (2016) Evaluating the performance of bioclimatic design building in Nigeria. Civil and Environmental Research, 8(5): 60-66.

[18] Ilter S (2018) Exploring design principles of bioclimatic architecture and double skin facades as a convincing tool for energy saving. Journal of Contemporary Urban Affairs, 2(3): 60-66. https://doi.org/10.25034/ijcua.2018.4719.

[19] Nag PK. Bioclimatic approach: Thermal environment. In: Office Building. Design Science and Innovation, Springer, Singapore, 2019, pp. 243-278. https://doi.org/10.1007/978-981-132577-9_9.

[20] Simeon OO, Alibaba HZ (2017) Bioclimatic approach for low operational energy in educational buildings in Nigeria. International Journal of Scientific \& Engineering Research, 8(12): 16701673.

[21] $\mathrm{Zr}$ LD, Mochtar S (2013) Application of bioclimatic parameter as sustainability approach on multi-story building design in tropical area. Procedia Environmental Science, 17: 822-830. https://doi.org/10.1016/j.proenv.2013.02.100.

[22] Motealleh P, Zolfaghari M, Parsaee M (2018) Investigating climate responsive solutions in vernacular architecture of Bushehr city. Housing and Building National Research Centre (HBRC) Journal, 14(2): 215-223. http://doi.org/10.1016/j.hbrcj.2016.08.001.

[23] Bondars E (2013) Implementing bioclimatic design in sustainable architectural practice. Architecture and Urban Planning, 7: 84-86.

[24] Pietrzyk K. Bioclimatic tools for sustainable design - Uncertainty perspective. International Building Physics Conference (IBPC 2018), 23-26 September 2018, Syracuse, NY, USA. https://doi.org/10.14305/ibpc.2018.gb-1.02.

[25] Samadzadehyazdi S, Khalili MJ, Samadzadehyazdi S, Mahdavinejad MJ (2018) Windphil poetic in architecture: Energy efficient strategies in modern buildings of Iran. World Academy of Science, Engineering and Technology International Journal of Civil and Environmental Engineering, 12(6): 651-658. https://doi.org/10.5281/zenodo.1317134.

[26] Aletta F, Kang J (2018) Towards an urban vibrancy model: A soundscape approach. International Journal of Environmental Research and Public
Health,

15(8):

1712

https://doi.org/10.3390/ijerph15081712.

[27] Aletta F, Kang J (2019) Promoting healthy and supportive acoustic environments: Going beyond the quietness. International Journal of Environmental Research and Public Health, 16(24): 4988. https://doi.org/10.3390/ijerph16244988.

[28] Marques G, Pitarma R (2019) Indoor air quality monitoring for enhanced health buildings. Mujeebu MA. (ed) Indoor Environmental Quality, IntechOpen, London. http://dx.doi.org/10.5772/intechopen.81478.

[29] Wilson J (2017) The sound of sustainability: Acoustics in high-performance design. The Building Green Report, 26(9): 1-19.

[30] Anumah JJ, Anumah L (2017) Building orientation: Enhancing nature with nature. Journal of Applied Science and Environmental Sustainability, 3(7): 29-35.

[31] Kunle AA, Adeniyi OS, Ronke OY (2013) Bioclimatic characteristics of residential building types in the traditional core of Ogbomoso, South West Nigeria. International Journal of Science, Environment and Technology, 2(6): 1462-1478.

[32] Zhang H, Wey WM, Chen SJ (2017) Demandoriented design strategies for low environmental impact housing in the tropics. Sustainability, 9: 1614. https://doi.org/10.3390/su9091614.

[33] Alabid J, Taki A (2014) Bioclimatic housing design to desert architecture: A case study of Ghadames, Libya. HVAC\&R Research, 20(7): 760-769. https://doi.org/10.1080/10789669.2014.953872.

[34] Geissler S, Macharm E. Energy efficiency for a sustainable built environment in Nigeria. World Sustainable Built Environment Conference, 5-7 June 2017, Hong Kong, pp. 591-597. Retrieved from: http://www.wsbe17hongkong.hk/.[Accessed 2 February 2020].

[35] Federal Republic of Nigeria. National Energy Efficiency Action Plans (NEEAP) (2015-2030). Federal Ministry of Power, Works and Housing, Abuja, Nigeria, 2016. Retrieved from: http://www.power.gov.ng/Press\%20Release/NATI ONAL\%20ENERGY\%20EFFICIENT\%20ACTIO N\%20PLANS.pdf. [Accessed 2 February 2020].

[36] Mohit MA, Raja AMMA (2014) Residential satisfaction - Concepts, theories and empirical studies. Planning Malaysia- Journal of Malaysian Institute of Planners, 3: 47-66. 
[37] Waziri AG, Yusof NA, Salleh, AG (2013) Residential satisfaction with private housing estate development in Abuja-Nigeria. International Journal of Sustainable Tropical Design Research and Practice, 6(2): 3-12.

[38] Jamaludin AA, Keumala N, Ariffin A M, Hussein $H$ (2014). Satisfaction and perception of residents towards bioclimatic design strategies: Residential college buildings. Indoor and Built Environment, 23(7): 933-945. https://doi.org/10.1177/142032X13481614.

[39] Okeke EC, Ene-obong HN, Uzuegbunam AO, Ozioko A, Umeh SI, Chukwuone N (2009) The Igbo traditional food system documentation in four states in Southern Nigeria. In: Kuhnlein HV, Erasmus B, Spigelski (eds) Indigenous Peoples' Food Systems: The Many Dimensions of Culture, Diversity and Environment for Nutrition and Health, Food and Agricultural Organisation and Centre for Indigenous Peoples' Nutrition and Environment, Rome, pp. 251-282.

[40] Madu IA (2006) Spatial inequality in Nigeria: The imperative of geographic perspectives in the development process. Journal of Social and Economic Development, 8(2): 105-120.

[41] Udechukwu NB, Agunwamba JC, Tenebe IT, Bamigboye GO. Geography of Udi cuesta contribution to hydro-meteorological pattern of the South Eastern Nigeria. In: Hromadka T, Rao P, (eds) Engineering and Mathematical Topics in Rainfall, IntechOpen, London, 2018. https://doi.org/10.5772/intech.72867.

[42] Ofomata GEK. Relief. In: Ofomata GEK, (ed) Nigeria in maps: Eastern States, Ethiope Publishing House, Benin, 1975, pp. 8-9.

[43] Ofomata GEK. Relief, drainage and landforms. In: Ofomata GEK, (ed) A Survey of Igbo Nation, Africana Publishers Ltd, Onitsha, 2002a, pp. 83-98.

[44] Monanu PC. Humidity. In: Ofomata GEK, (ed) Nigeria in maps: Eastern States, Ethiope Publishing House, Benin, 1975a, pp. 19-21.

[45] Anyadike, RNC. Climate and vegetation. In: Ofomata GEK, (ed) A Survey of Igbo Nation, Africana Publishers Ltd, Onitsha, 2002, pp. 73-82.

[46] Monanu PC. Temperature and sunshine. In: Ofomata GEK, (ed) Nigeria in maps: Eastern States, Ethiope Publishing House, Benin, 1975b, pp. 16-18.

[47] Onokala PC, Phil-Eze PO. Environmental problems of rural transport development in Nigeria. In: Ofomata GEK Phil Eze PO, (eds) Geographical
Perspectives on Environmental Problems and Management in Nigeria, Jamoe Enterprises Nigeria, Enugu 2001.

[48] Umeji AC. Geology. In: Ofomata GEK, (ed) A Survey of Igbo Nation, Africana Publishers Ltd, Onitsha, 2002, pp. 56-72.

[49] Ofomata GEK. Soils and soil erosion. In: Ofomata GEK, (ed) A Survey of Igbo Nation, Africana Publishers Ltd, Onitsha, 2002b, pp. 99-116.

[50] Auwalu FK (2019) Exploring the different vernacular architecture in Nigeria. International Journal of African Society, Cultures and Traditions, 7(1): 1-12.

[51] National Population Commission (NPC). The 2006 Nigeria demographic and health survey: findings and implications for action, South East Zone. Government Printer, Abuja, 2006.

[52] Lodson J, Ogbeba JE, Elinwa UK (2018) A lesson from vernacular architecture in Nigeria. Journal of Contemporary Urban Affairs, 2(1): 84-95. https://doi.org/10.25034/ijcua.2018.3664.

[53] Chukwu JC (2015) Traditional Igbo building architecture: An historical perspective. Journal of Art and Design Studies, 34: 7-14.

[54] Okoye CB, Ukanwa OE (2019) Igbo traditional architecture: A symbol of Igbo cultural identity. International Journal of Scientific \& Engineering Research, 10(11): 84-88.

[55] Uduku O (1996) The urban fabric of Igbo architecture in South-eastern Nigeria in the 1990s. Habitat International, 20(2): 191-202. https://doi.org/10.1016/0197-3975(95)00052-6.

[56] National Bureau of Statistics. Nigeria living standards survey: A survey report by the Nigerian National Bureau of Statistics (in collaboration with the World Bank) 2018/19. National Bureau of Statistics, Abuja, 2020. Retrieved from www.nigeranstat.gov.ng. [Accessed 14 September 2020].

[57] National Bureau of Statistics. 2019 poverty and inequality in Nigeria: Executive summary. National Bureau of Statistics, Abuja, 2020. Retrieved from www.nigeranstat.gov.ng. [Accessed 14 September 2020].

[58] Ajiboye AD (2014) Significance of house-type as a determinant of residential quality in Osogbo, Southwest Nigeria. Frontiers of Architectural Research, 3(1): 20-27. https://doi.org/10.1016/j.foar.2013.11.006.

[59] Ibem EO, Opoko AP, Adeboyea AB, Amole D (2013) Performance evaluation of residential 
buildings in public housing estates in Ogun State, Nigeria: Users' satisfaction perspective. Frontiers of Architectural Research, 2: 178-190. https://doi.org/10.1016/j.foar.2013.02.001.

[60] Makinde OO (2015). Influences of socio-cultural experiences on residents' satisfaction in Ikorodu low-cost housing estate, Lagos state. Environment, Development and Sustainability, 17(1): 173-198. https://doi.org/10.1007/s10668-014-9545-6.

[61] Okpoko PU, Okpoko C (2016) Socio-cultural profiling and development of Southeast Nigeria: A case study. Mediterranean Journal of Social Sciences, $\quad 7(5)$ : 212-224. https://doi.org/10.5901/mjss.2016.v7n5p212.

[62] Abdu A, Hashim AH, Samah AA, Salim ASBS (2014) Comparison of satisfaction with residential components between previous and current unplanned neighbourhoods among young households in Kano, Nigeria. Research on Humanities and Social Sciences, 4(23): 27-34.

[63] Abidin NZ, Abdullah MI, Basrah N, Alias MN (2019) Residential satisfaction: Literature review and a conceptual framework. IOP Conference Series: Earth and Environmental Science, 385: 012040. https://doi.org/10.1088/17551315/385/1/012040.

[64] Huber C, Koch D, Busko S (2014) An international comparison of user satisfaction in buildings from the perspective of facility management. International Journal of Facility Management, 5(2).

[65] Ibem EO, Aduwo EB (2013) Assessment of residential satisfaction in public housing in Ogun State, Nigeria. Habitat International, 40: 163-175. https://doi.org/10.1016/j.habitatint.2013.04.001.

[66] Voelker C, Beckmann J. Koehlmann S, Kornadt O (2013) Occupant requirements in residential buildings: An empirical study and a theoretical model. Advances in Building Energy Research, 7(1): 35-50. https://doi.org/10.1080/17312549.2012.749808.

[67] Andargie MS, Touchie M, O’Bren W (2019) A review of factors affecting occupant comfort in multi-unit residential buildings. Building and Environment, $\quad 160$ : 106182. https://doi.org/10.1016/j.buildenv.2019.106182.

[68] Ikaga T. Architecture for a sustainable future: All about the holistic approach in Japan. Institute of Building Environment and Energy Conservation (IBEC), Tokyo, Japan, 2005.

[69] Xue P, Mak CM, Ai ZT (2016) A structural approach to overall environmental satisfaction in high-rise residential buildings. Energy and Buildings, $\quad 116$ : 181-189. https://doi.org/10.1016/j.enbuild.2016.01.006.

[70] Ahmed AF, Khan KMK, Maung Than Oo, A, Rasul RG (2014) Selecting suitable passive cooling strategy for a subtropical climate. International Journal of Mechanical and Materials Engineering, 9(14). https://doi.org/10.1186/s40712-014-0014-7.

[71] Bajcinovci B, Jerliu F (2016) Achieving energy efficiency in accordance with bioclimatic architecture principles. Environmental and Climate Technologies, 18: 54-63. https://doi.org/10.1515/rtuect-2016-0013.

[72] Jaafaru F. An assessment of bioclimatic design principles in optimising energy efficiency in design of state convention centre, Kaduna. MSc. Thesis, Department of Architecture, Ahmadu Bello University, Zaria, Nigeria, 2015.

[73] Kartal S, Chousein Ö (2016) Utilisation of renewable energy sources in bioclimatic architecture in Greece. World Journal of Engineering, 13(1): 18-22. https://doi.org/10.1108/WJE-02-2016-002.

[74] Spinelli R, Konrad O, Cambeiro FP, Ahlert E, Spinelli FB, Quadros EA (2017) Bioclimatic strategies for the city of Lajeado/RS-Brazil, using data analysis of regional climate. Ravista Brasileira de Climatologia, 21: 153-171. http://dx.doi.org/10.5380/abclima.v21i0.50554.

[75] Jamaludin AA. Satisfaction and perception of residents with bioclimatic design strategies - A findings from racial and ethnic perspectives. Proceedings of USM International Conference on Social Sciences 2015 (USM-ICOSS 2015), 27-28 August 2015, Rainbow Paradise Beach Resort, Panang, Malaysia, pp.328-335.

[76] Couvelas A (2020). Bioclimatic building design theory and application. Procedia Manufacturing, 44: 326-333. https://doi.org/10.`0 6/j.promfg.2020.02.238.

[77] Azzouz A, Borchers M, Moreira J, Mavrogianni A (2017) Life cycle assessment of energy conservation measures during early stage office building design: A case study in London, UK. Energy and Buildings, 139: 547-568. https://doi.org/10.1016/j.enbuild.2016.12.089.

[78] Miller W, Buys L (2012) Anatomy of a sub-tropical positive energy home (PEH). Solar Energy, 86(1): 231-241.

https://doi.org/10.1016/j.solener.2011.09.028. 
[79] Bughio M, Schuetze T, Mahar WA (2020) Comparative analysis of indoor environmental quality of architectural campus buildings' lecture halls and its perception by building users in Karachi, Pakistan. Sustainability, 12: 2995. https://doi.org/10.3390/su12072995.

[80] Kürüm Varolgüneş F (2019) Evaluation of vernacular and new housing indoor comfort conditions in cold climate - A field survey in eastern Turkey. International Journal of Housing Markets and Analysis, 13(2): 207-226. https://doi.org/10.1108/IJHMA-02-2019-0019.

[81] Mohammed UA, Alibaba HZ (2018) Application of bioclimatic design strategies to solve thermal discomfort in Maiduguri residences, Borno State Nigeria. Imperial Journal of Interdisciplinary Research (IJIR), 4(1): 227-233.

[82] Adedayo OF, Ayuba P, Oyetola S, Buhari A (2013) Bioclimatic design principle a solution to thermal discomfort in Minna residences, Niger State Nigeria. Journal of Environment and Earth Science, 3(12): 45-51.

[83] Yusuf A (2020) Evaluation of bioclimatic principles in the design of office building in hot-dry climate region of Nigeria. International Journal of Engineering Research and Technology, 9(4): 820826. http://dx.doi.org/10.17577/IJERTV940506.

[84] Odunfa KM, Nnakwe CJ, Odunfa VO (2018) Building energy efficiency in Nigeria major climatic zones. Journal Building Construction and Planning Research, 6: 251-266. https://doi.org/10.4236/jbcpr.2018.64017.

[85] Okoye PU, Ngwu C, Ohaedeghasi CI (2020) Assessment of acoustical performance of residential buildings for sustainable liveability and satisfaction in Awka Anambra State Nigeria. Asian Journal of environment \& ecology, 12(3): 25-37. https://doi.org/10.9734/ajee/2020/v12i330160.

[86] Daemei AB, Eghbali SR, Khotbehsara EM (2019) Bioclimatic design strategies: A guideline to enhance human thermal comfort in CFA climate zones. Journal of Building Engineering, 25: 100758 . https://doi.org/10.1016/j.jobe.2019.100758.

[87] National Population Commission (NPC). Population and housing census of the Federal Republic of Nigeria. National and State Population and Housing Tables, Priority Tables, 1. 26 October 2019. Retrieved from: www.population.gov.ng. [Accessed 10 June 2020].
[88] Israel GD. Determining sample size. Agricultural Education and Communication Department, UF/IFAS Extension, University of Florida, PEOD6, Reviewed version, 2013. Retrieved from: http://edis.ifas.ufl.edu. [Accessed 10 June 2020].

[89] Cochran WG. Sampling techniques (3rd ed). John Wiley \& Sons Inc, New York, 1977.

[90] Chee JD. Pearson's Product-Moment Correlation: Sample analysis. University of Hawaii at Mānoa School of Nursing, 2013.

[91] DataStar. What every researcher should know about statistical significance. DataStar Inc, Waltham, MA, USA, 2008. Retrieved from: https://www.surveystar.com/startips. [Accessed 8 June 2020]. 